\title{
Recent Improvements to the U.S. Geological Survey Streamgaging Program ... from the National Streamflow Information Program
}

\begin{abstract}
This Fact Sheet is one in a series that highlights information or recent research findings from the U.S. Geological Survey National Streamflow Information Program (NSIP). The investigations and scientific results reported in this series require a nationally consistent streamgaging network with stable long-term monitoring sites and a rigorous program of data, quality assurance, management, archiving, and synthesis. NSIP produces multipurpose, unbiased surface-water information that is readily accessible to all.
\end{abstract}

\section{Introduction}

The U.S. Geological Survey (USGS) established its first streamgage in 1889 on the Rio Grande River at Embudo, N.M. As the need for streamflow information increased, the USGS streamgaging network expanded to its current (2007) size of approximately 7,400 streamgages nationwide.

The USGS streamgaging network, for most of its history, required mechanical measuring and recording devices to collect station data. Time-consuming and labor-intensive site visits were required to gather the recorded data for processing in the office. Eventually the data were published in paper reports. The USGS has progressively improved the streamgaging program by incorporating new technologies and techniques that streamline data collection, data delivery, and records processing while increasing the number and quality of product types that can be derived from the data. Improvements in recent decades that have expanded and broadened the streamgaging program are highlighted below.

\section{Streamflow Data Collection and Processing}

Streamgaging generally involves (1) obtaining a continuous record of stage (height of water), (2) obtaining periodic measurements of discharge, (3) defining the relation between the stage and the discharge, (4) using the stage-discharge relation to convert the continuous record of stage into a record of discharge, and (5) disseminating the streamflow information to a multitude of users, including water managers, scientists, engineers, and the general public.
River stage was traditionally measured with a float and tape system from inside a stilling well (fig. 1) and recorded on a paper graph or tape. This method of stage measurement served the USGS well over many years but with some drawbacks. Stilling-well systems are expensive to install, tend to fill with sediment, can be damaged when the pipes in the river move or are destroyed by floods, and cause human safety problems because of the confined space. The mechanical-paper recording devices resulted in poor timekeeping, lost data, and labor-intensive processing.

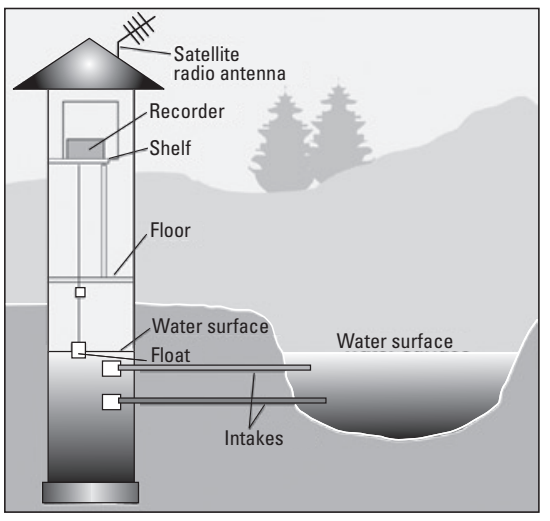

Figure 1. Stage measurement using a stilling well, float, and recorder.

To overcome most of the drawbacks with the stilling-well system, the USGS has been using various pressure-sensing devices to measure stage (fig. 2), and electronic data loggers to record data.

Pressure systems transmit gas through a small-diameter tube into the river. The pressure generated is directly proportional to the height of the water, and thus the river stage can be determined. Many of

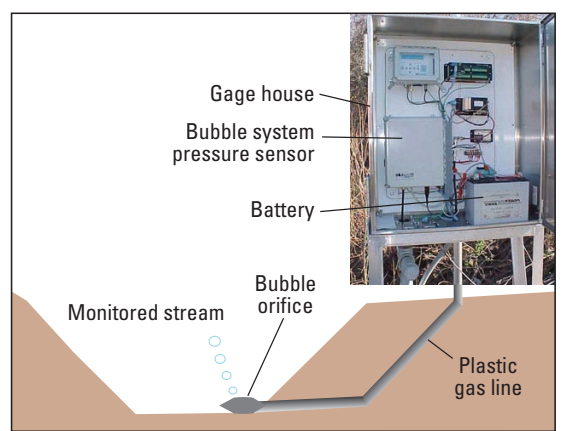

Figure 2. Measurement of stage using a pressure-sensing device.

the challenges associated with stilling wells are avoided with pressure systems, which have lower installation and maintenance costs and reduced safety concerns.

A major development in stagemeasuring technology beginning to be deployed by the USGS for special conditions is the non-contact radar stage sensor (fig. 3). This device measures the height of the river without touching the water. The radar stage sensor is simple and cost effective to install; is located above the river so it is much less susceptible to being moved or destroyed by debris or floods; eliminates the confined space safety issue; and, as a result of all of the above, is economical to operate and maintain.

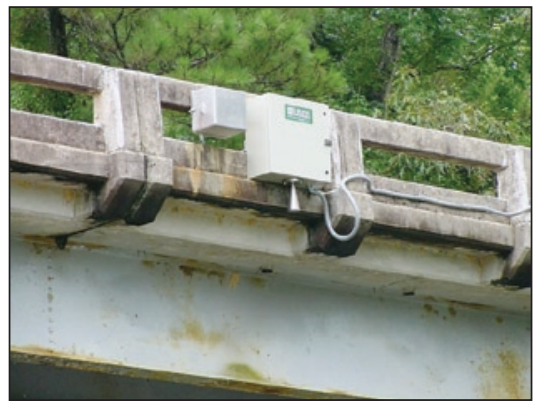

Figure 3. Stage can be measured using a noncontact radar stage sensor mounted on a bridge. 


\section{Measurement of Discharge}

Historically, the USGS measured river discharge through physical measurements of the water velocity and cross-sectional area of the river using a mechanical current meter placed directly into the water (fig. 4).

The mechanical instruments used to measure discharge worked well and have a proven track record; however, they are labor intensive to use, hinder measurements in difficult locations and under extreme flow conditions, and can place hydrographers in dangerous situations. For these reasons, the USGS has pursued the use of new and emerging technologies to improve discharge measurements.

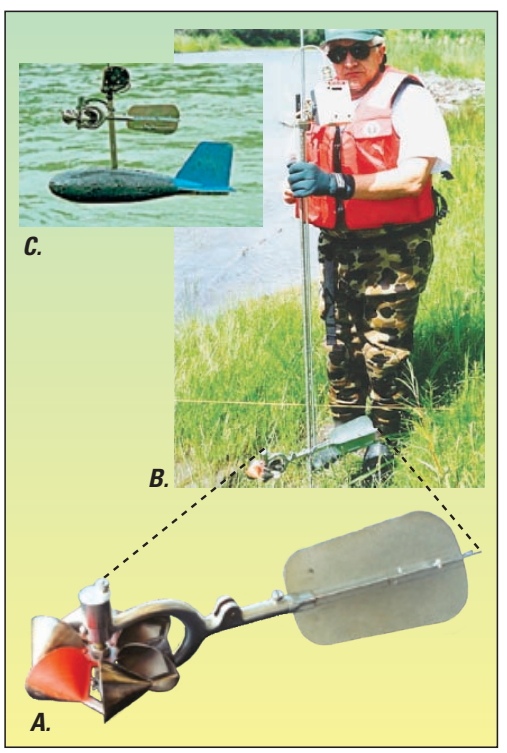

Figure 4. Current-meter method equipment. $A$, Price AA current meter. $B$, Current meter attached to a wading rod. $C$, Current meter suspended from a weightcable system (Olson and Norris, 2007; photograph by Michael Nolan, USGS).

For the last 10 to 15 years the USGS gradually has been replacing mechanical meters with hydroacoustic meters for discharge measurements. Hydroacoustic meters currently (2007) are used to make about 30 percent of USGS discharge measurements. Hydroacoustic meters use the Doppler shift to measure water velocity. Pulses of sound originate from a transducer, travel through the water, and are reflected back to the transducer when the pulse bounces off of solid particles in the water. The shift in the frequency of the sound is proportional to the velocity of the solid particles moving in the water. The velocity of the solid particles is assumed to be the same as the water velocity. Hydroacoustic meters, such as

the acoustic Doppler velocimeter (ADV), can be mounted on a wading rod (fig. 5), allowing discharge measurements to be taken while wading in a stream. ADVs provide a more accurate flow measurement during low-flow and drought conditions than does a mechanical meter.

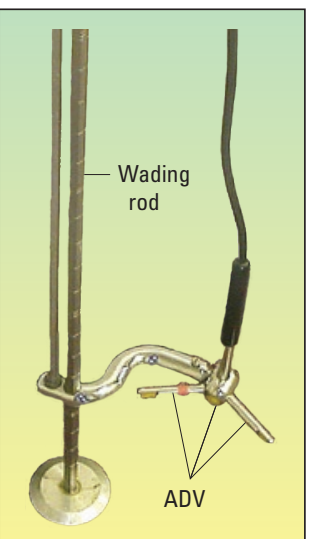

More complex acoustic meter systems, such as the acoustic Doppler current profiler (ADCP; fig. 6), are used to measure water velocity, water depth, and boat velocity. Onboard computers then calculate the discharge. The ADCP can be mounted on a variety of platforms (fig. 7), such as manned boats, tethered boats connected to an operator by a rope or cable and used from a bridge or cableway, and remotely controlled boats operated from shore. The USGS continues to work with hydroacoustic instrument manufacturers to develop instruments that meet the needs and requirements of the USGS.

Hydroacoustic instrumentation greatly improves the ability of the USGS to make discharge measurements under extreme flow conditions and in difficult measuring locations. The ADCP has improved the quality of the measurements by providing more detailed information about the river flow. ADCPs are the most efficient method for measuring discharge, taking minutes rather than the hours associated with other methods (table 1).

Hydroacoustic meters allow the USGS to downsize the vehicles needed for field work. Instead of large trucks to transport heavy cranes, reels, and weights for use with mechanical meters, the USGS increasingly uses more economical vehicles to carry the smaller, lighter hydroacoustic equipment.

The ideal method for measuring discharge would be to measure it continuously without contacting the water. Recent research conducted by the USGS has shown that it is possible to use several types of radar instruments to measure both the surface velocity of

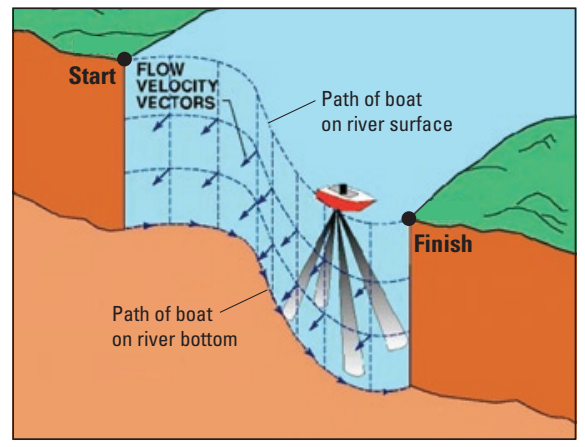

Figure 6. River discharge measured using an acoustic Doppler current profiler mounted on a boat.

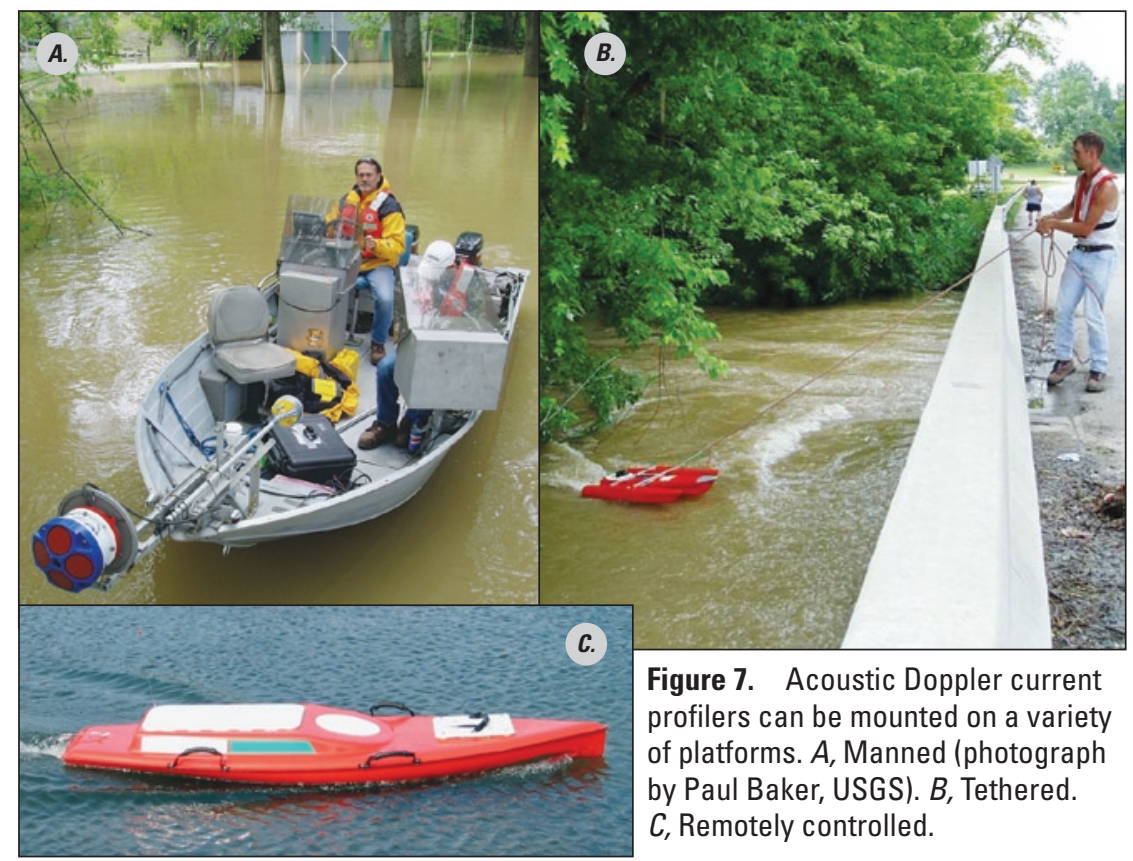


the water (fig. 8) and the cross-sectional area of the river so that discharge can be monitored continuously without contacting the water.

Table 1. Acoustic Doppler current profilers (ADCPs) — used in Indiana to measure discharge during a July 2003 flood - greatly increased the efficiency of measurement in terms of time and staff compared to mechanical current meters used in a January 1991 flood.

\begin{tabular}{cccc}
\hline $\begin{array}{c}\text { Flood month } \\
\text { and year }\end{array}$ & $\begin{array}{c}\text { Discharge } \\
\text { measure- } \\
\text { ments, in } \\
\text { 10 days }\end{array}$ & $\begin{array}{c}\text { Average } \\
\text { time per } \\
\text { discharge } \\
\text { measure- } \\
\text { ment, in } \\
\text { minutes }\end{array}$ & $\begin{array}{c}\text { Hydro- } \\
\text { graphers }\end{array}$ \\
\hline $\begin{array}{c}\text { January 1991 } \\
\text { (Current } \\
\text { meters) }\end{array}$ & 52 & 96 & 11 \\
$\begin{array}{c}\text { July 2003 } \\
\text { (ADCPs) }\end{array}$ & 62 & 18 & 6 \\
\hline
\end{tabular}

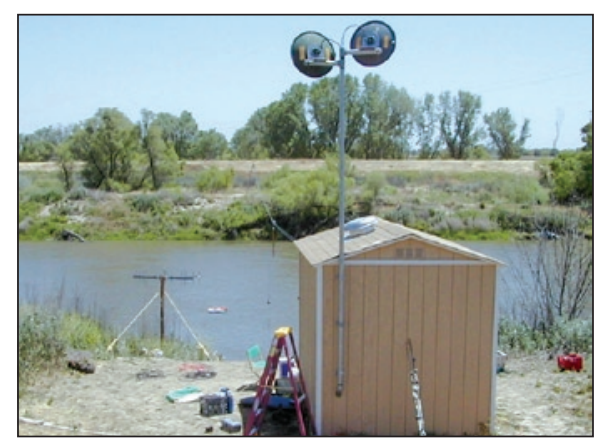

Figure 8. Ultra-high frequency (UHF) and microwave radar system can measure the surface velocity of a river.

\section{Stage-Discharge Relation}

Periodic discharge measurements, typically at intervals of every 6 to 8 weeks, paired with concurrent measurement of the river stage are used to create and maintain a rating curve (see figure 9 for a graph showing the relation of stage to discharge). Over time, however, river channels can change and shift due to erosion of the bed or bank, deposition of sediment, movement of dunes or bars, and changes in aquatic vegetation. It is often necessary to apply a temporary shift to the primary rating curve (fig. 9) to account for the changed stage-discharge relation. Periodic discharge measurements are made to maintain the relation.

USGS hydrographers spend considerable time developing and maintaining these rating curves and determining appropriate shifts to compute the discharge record. Until recently, the USGS manually developed and maintained all rating curves

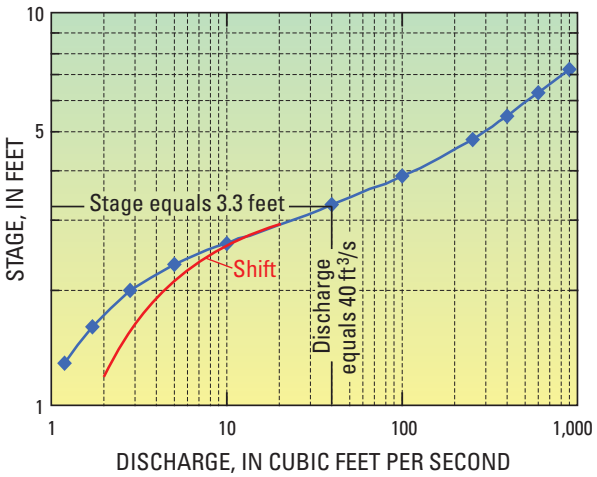

Figure 9. Example of a stage-discharge rating curve showing increasing stage upward on the $y$-axis and increasing discharge outward on the $\mathrm{x}$-axis. A shift to the rating curve is indicated by the red line.

and shifts. In 2006, the USGS completed work with a software vendor on the development of a Graphical Ratings and Shift Application Tool (GRSAT). The GRSAT allows the user, through a computer graphical user interface, to build rating curves and apply shifts (fig. 10). Use of GRSAT over the past year has shown that about 8 hours of labor are saved on average each year per streamgage — a significant cost savings when applied to the national network of approximately 7,400 gages.

\section{Index-Velocity Streamgage}

For some rivers, the typical stagedischarge relation does not apply because water height cannot be uniquely related to discharge. These rivers are typically affected by tides, have little slope, or experience density currents. Sites on these rivers have been very difficult or even impossible to measure. However, with the development of hydroacoustic and ultrasonic velocity meters, continuous records of stream discharge for these types of rivers can be determined. To do this, a hydroacoustic or ultrasonic velocity meter is placed in the river (fig. 11) to continuously monitor the water velocity for a section of the river; this is called the index velocity. Periodic discharge measurements are paired with the index velocity to develop a relation between the index velocity and the mean velocity. This index velocity versus mean velocity relation is used along with a continuous record of the stage and a stage versus cross-sectional area relation to determine the continuous record of discharge at these sites. These meters and index-velocity-type gaging stations allow the USGS to routinely measure streamflow along the coastal parts of the Nation.

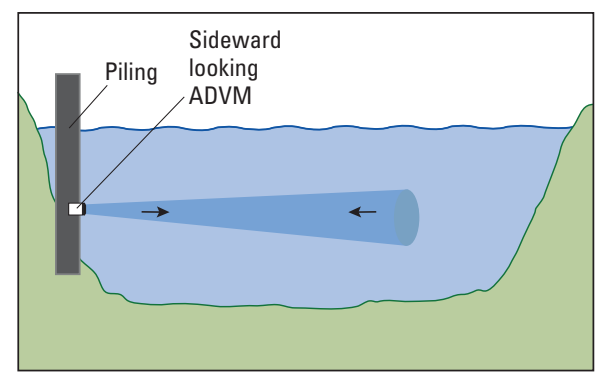

Figure 11. Sideward looking acoustic Doppler velocity meter (ADVM) used to continuously measure a river index velocity (Ruhl and Simpson, 2005).

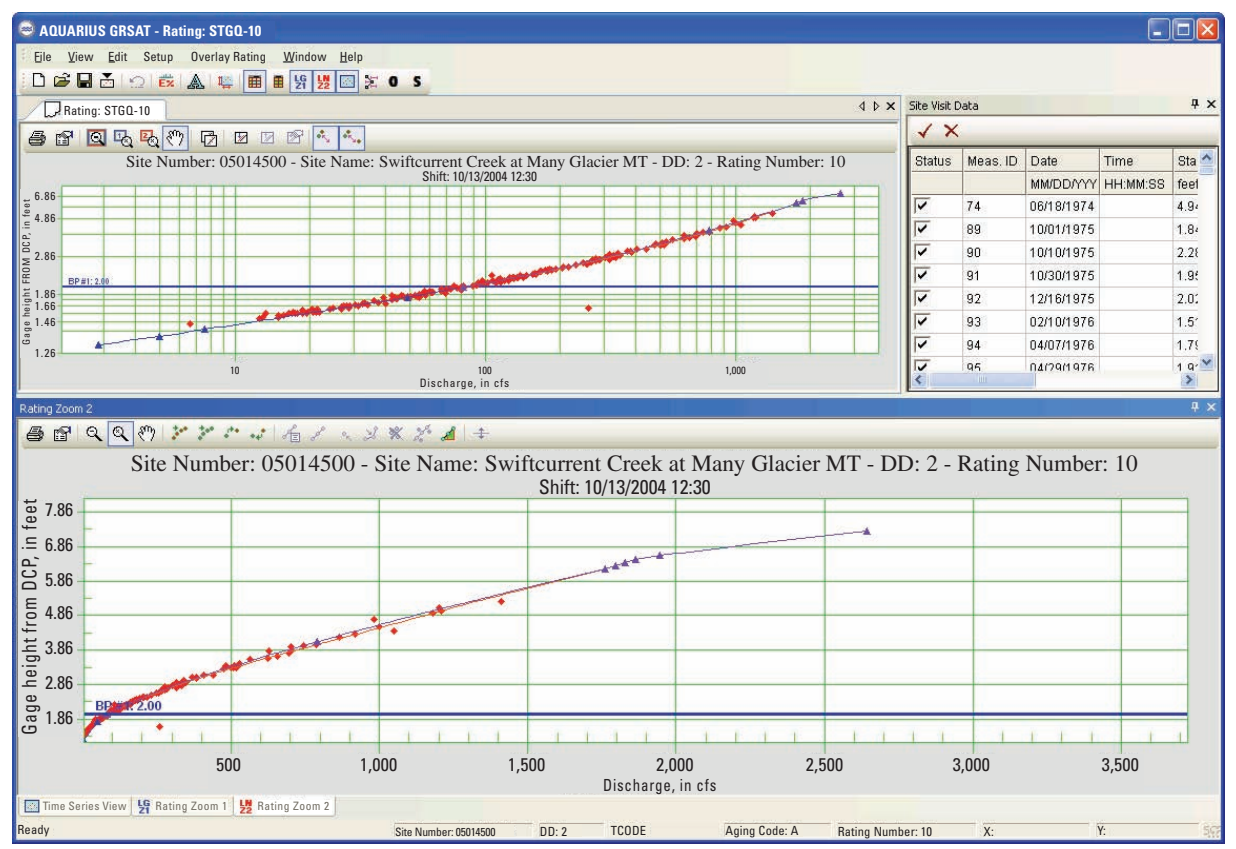

Figure 10. View of a Graphical Rating and Shift Application Tool (GRSAT) screen. GRSAT has been developed to build and maintain rating curves. 


\section{Flood Hardening of Streamgages}

Because of their primary purpose and close proximity to water, USGS streamgages are often vulnerable to flooding and other potentially destructive hazards. As part of continuous improvements to its streamgaging program, the USGS is beginning to strengthen or "harden" its gages. Hardening a streamgage generally means modifying the structure to be able to withstand a flood with an estimated 200-year recurrence interval. In most cases, hardening involves raising the structure to a higher elevation, improving the structural integrity of the instrument shelter, and upgrading the data transmission capabilities. In fiscal year 2005, the USGS received a Congressional supplemental appropriation for the purpose of hardening streamgages that were impacted by Hurricanes Katrina and Rita in the Gulf Coast States. The USGS is using these funds to harden about 130 streamgages within 100 miles of the Gulf Coast that also serve as National Weather Service flood forecast sites.

\section{Streamflow Information}

The goal of the USGS National Streamflow Information Program (NSIP) is to provide timely streamflow information to a multitude of users, including water managers, scientists, and the general public. For most of the last 100 years, the stage and discharge data and streamflow statistics have been made available annually through printed reports. Streamflow data in these reports in recent decades were usually available about 7 months (at the earliest) after the end of the previous water year.

\section{Streamflow Information on the Internet}

The annual USGS Water Resources Data Report, which serves as the citable reference for published USGS water data, is now available electronically. Approved, citable USGS streamflow data can be accessed through the Internet by using a text-based search (http://web10capp. er.usgs.gov/adr06_lookup/search.jsp) or by using a map interface search (fig. 12) (http://web10capp.er.usgs.gov/imf/sites/ adr06/launch2.jsp).

Significant advancements have been made in developing a database and

Welcome to the Annual Water Data Reports Mapper Launch Page. The Mapper allows users to geographically locate surface water, ground water, and climatological sites and view and download published water data for those sites. Each site on the map links to a downloadable PDF file of the water record for that site.

(Depending on your browser, you may need to allow popups from web10capp.er.usgs.gov.)

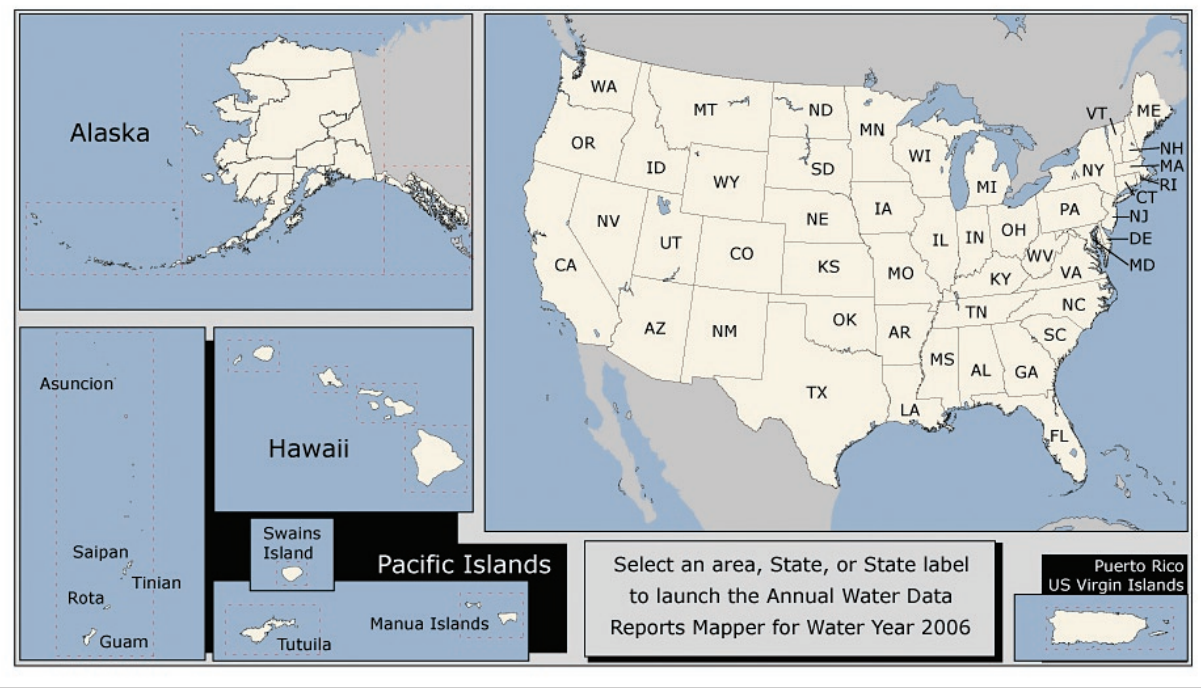

Figure 12. View of the Annual Water Data Reports Mapper Launch Page (http://web10capp. er.usgs.gov/imf/sites/adr06/launch2.jsp).

system to provide streamflow information electronically, in real time (updated at 1- to 4-hour intervals) over the Internet through the USGS National Water Information System (NWIS). To access real-time streamflow information from the USGS, a user simply goes to the Web page http://waterdata.usgs.gov/nwis/rt (fig. 13) and clicks on the State of their choice; after the State map comes up, the user clicks on the streamgage of interest, and the real-time river stage and discharge are displayed. The many uses of streamflow data are enhanced by making these data available quickly to a wide audience. Recreationists can use current information to plan their outings. During floods, real-time streamflow data contribute to saving lives and property.

The USGS also provides historic daily values of stage and discharge; annual instantaneous peak stage and discharge values; discharge measurements; and daily, monthly, and annual streamflow statistics through NWIS (http://waterdata.usgs.gov/nwis/sw).

Figure 13. Streamflow data area available in real time from the USGS National Water Information System (http://water.usgs.gov/ waterwatch/. Maps of real-time streamflow are compared to historical streamflow for the day and year.

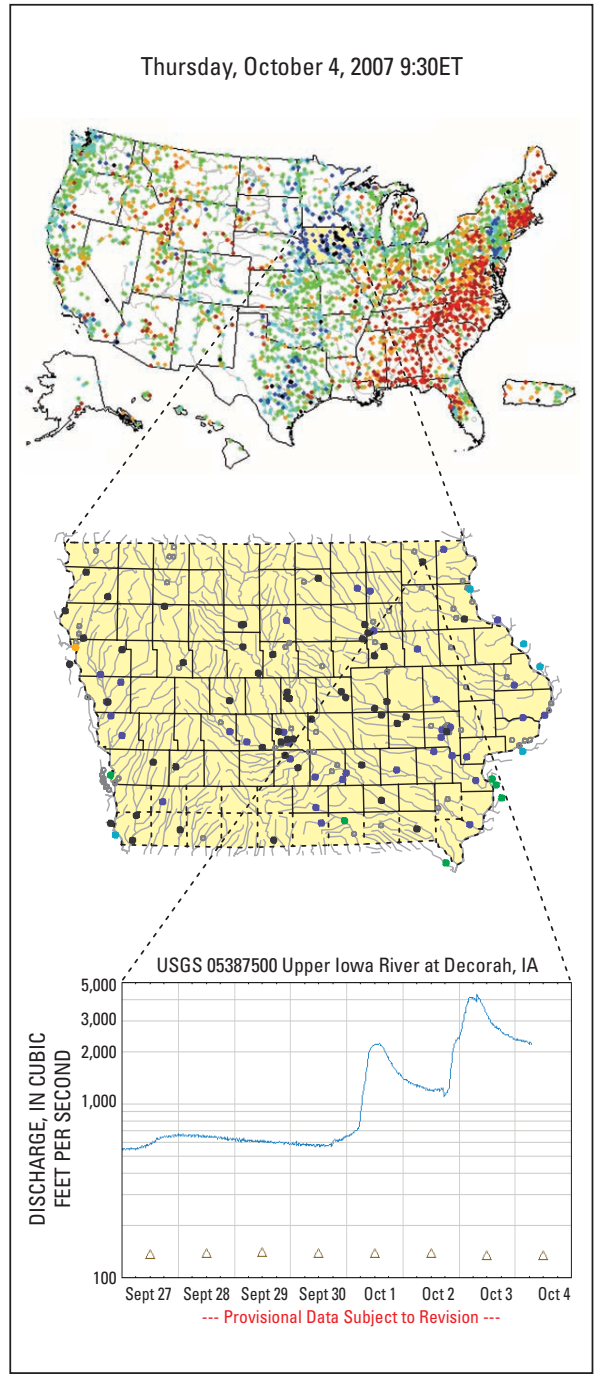




\section{Historic Instantaneous Streamflow Data}

USGS instantaneous streamflow values, usually recorded at 15 -minute intervals, generally have been available over the Internet for only the previous 31 days. A long-term electronically available archive of historic instantaneous values of streamflow, however, are important to many users, such as the National Weather Service, the Army Corps of Engineers, and consulting engineers for (1) hydraulic and hydrologic modeling for flood-plain mapping, flood routing, and issuing flood forecasts and warnings, and (2) estimating pollutant transport. In response, the USGS developed an Instantaneous Data Archive (IDA; http://ida.water.usgs. gov/ida/index.cfm) that provides historic instantaneous data available in electronic form through the Internet back to about 1990. This database has recently been made available to the general public, although information is not available for all streamgaging stations in each State. This is an ongoing effort within the USGS, as resources are made available.

\section{Satellite Telemetry}

The USGS uses satellite telemetry as its primary method to transmit streamflow data from the streamgage to the NWIS for processing (fig. 14). The original radios installed in streamgages transmit data to the satellite once every 4 hours. Once the data are transmitted, it takes on average about 7 minutes for the data to move from the streamgage, through NWIS processing, to posting on the Internet. The transmission of data once every 4 hours is often not sufficient for smaller streams and locations that have rapid increases and decreases in streamflow. The satellite radios have recently been improved to allow transmissions once every hour and as rapid changes in stage occur. The USGS is upgrading streamgages by installing new high-speed satellite radios so that routine transmissions will be made once every hour. Currently (2007), about 2,500 of the approximately 7,000 streamgages with satellite telemetry have had these new satellite radios installed. The USGS plans to complete the conversion to the new satellite radios by the end of 2013 .

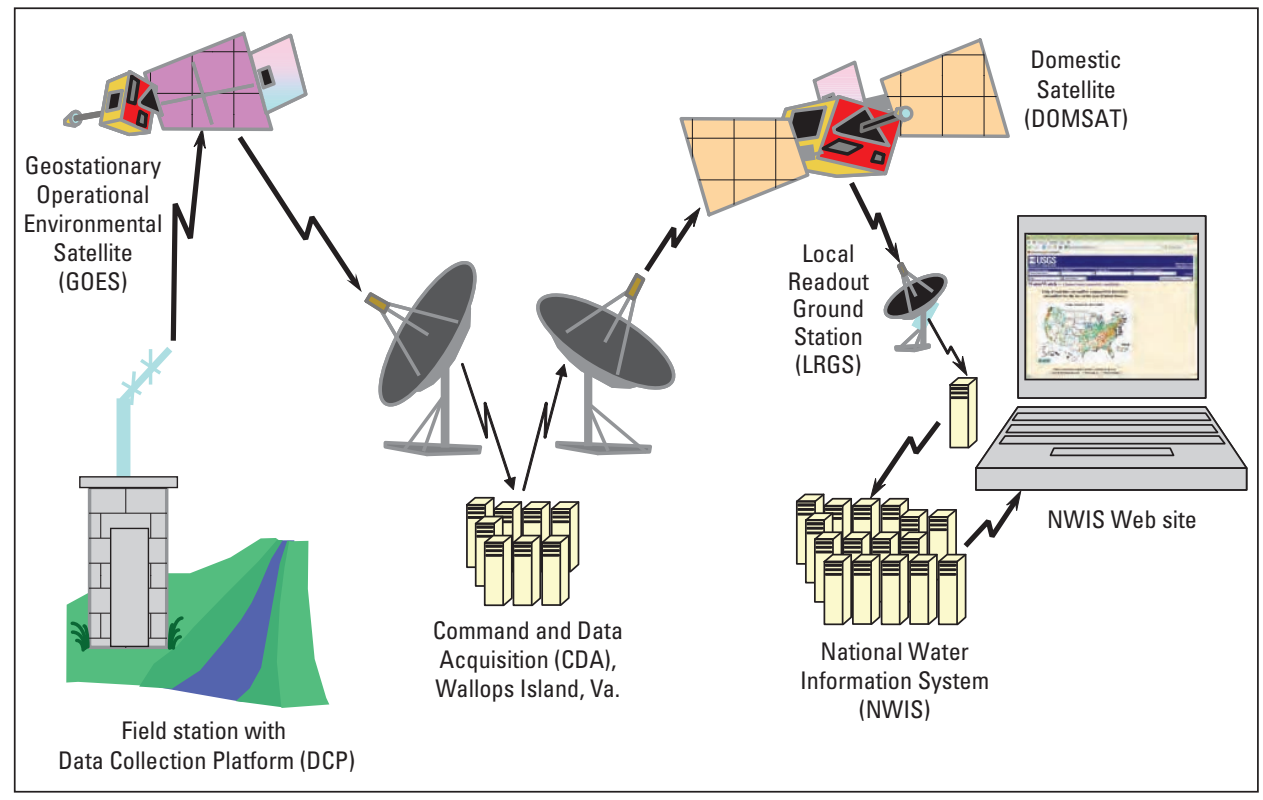

Figure 14. Satellite telemetry is used to transmit near real-time data from streamgages to the USGS National Water Information System for processing (from Nielsen and Norris, 2007).

\section{Satellite Telemetry and Ground Station Backup}

All of the streamflow data transmitted by satellite telemetry goes through a single data acquisition system operated by the National Oceanic and Atmospheric Administration (NOAA), at Wallops Island, Va. The USGS, NOAA, and many other partners and data users recognize the potential for interruptions to satellite telemetry capability and continuous national data if the Wallops Island facility was not able to function for some reason, such as a hurricane strike. Virtually all satellite telemetry capability across the United States would be lost until the Wallops Island facility could be restored to operation. The USGS, therefore, is partnering with NOAA and other Federal agencies to establish a backup system at the USGS Earth Resources and Observation Science (EROS) facility located near Sioux Falls, S.D. This backup system is expected to be operational by the end of 2007 and will help to ensure uninterrupted satellite telemetry.

\section{Real-Time Data Quality Assurance}

The USGS values its reputation for credible and accurate data, and recognizes the critical need to flag, as quickly as possible, potentially erroneous real-time information that might result from equipment malfunctions or sud- den physical changes to a stream. Even though such data are identified as provisional and subject to change, it is important that the real-time streamflow data be as accurate as possible. The USGS, therefore, has developed quality-assurance software to (1) identify potentially erroneous data, which usually appears in the form of a "data spike," and (2) to alert the appropriate USGS Water Science Center to its existence so the data can be checked and corrected if necessary.

Alerts are sent daily by e-mail to hydrographers responsible for the affected streamgage. Since implementation of the quality-assurance software in 2002, the number of potentially erroneous data displayed on the Internet have dropped to almost negligible levels (fig. 15).

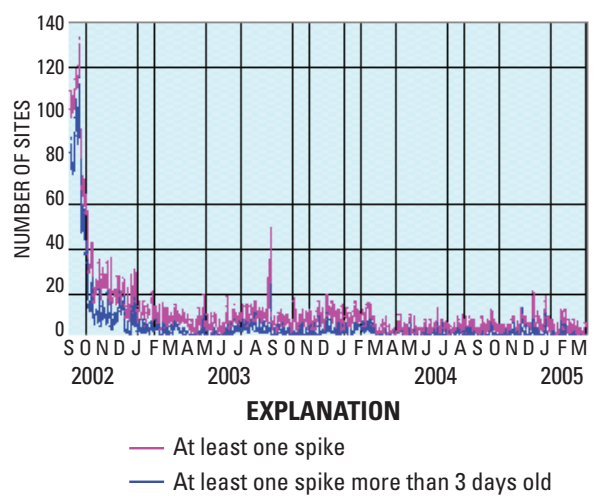

Figure 15. The number of data spikes (reflecting potential errors) in real-time streamflow data has diminished substantially since the installation of the quality-assurance software in 2002. 


\section{Robust Data-Delivery Network}

Users of the USGS real-time streamflow information include those who use the streams for recreation, as well as those who require the data for daily operational needs. Many of these organizations could not carry out their missions without reliable access to the real-time streamflow information provided by the USGS. For this reason, the USGS has invested significant resources to develop a robust datadelivery network to ensure that real-time data are available when needed. The USGS provides real-time streamflow data through computer servers located in three locations: Menlo Park, Calif.; Sioux Falls, S.D.; and Reston, Va. Requests for real-time data are directed to the server location with the least workload so that data requests are met as rapidly as possible. The servers also function as backups; if one location ceases to function, the other two locations will continue to provide data. Additionally, the USGS built a system to provide backup real-time data receiving and processing capabilities (fig. 16). Through this system, real-time data for the States in the eastern half of the United States are received by servers at Menlo Park, Calif. Similarly, the real-time data in the western half of the United States are received by the servers in Reston, Va. This backup system ensures that real-time data can be processed and posted to the Internet should any one of the USGS State Water Science Centers not be able to do so.

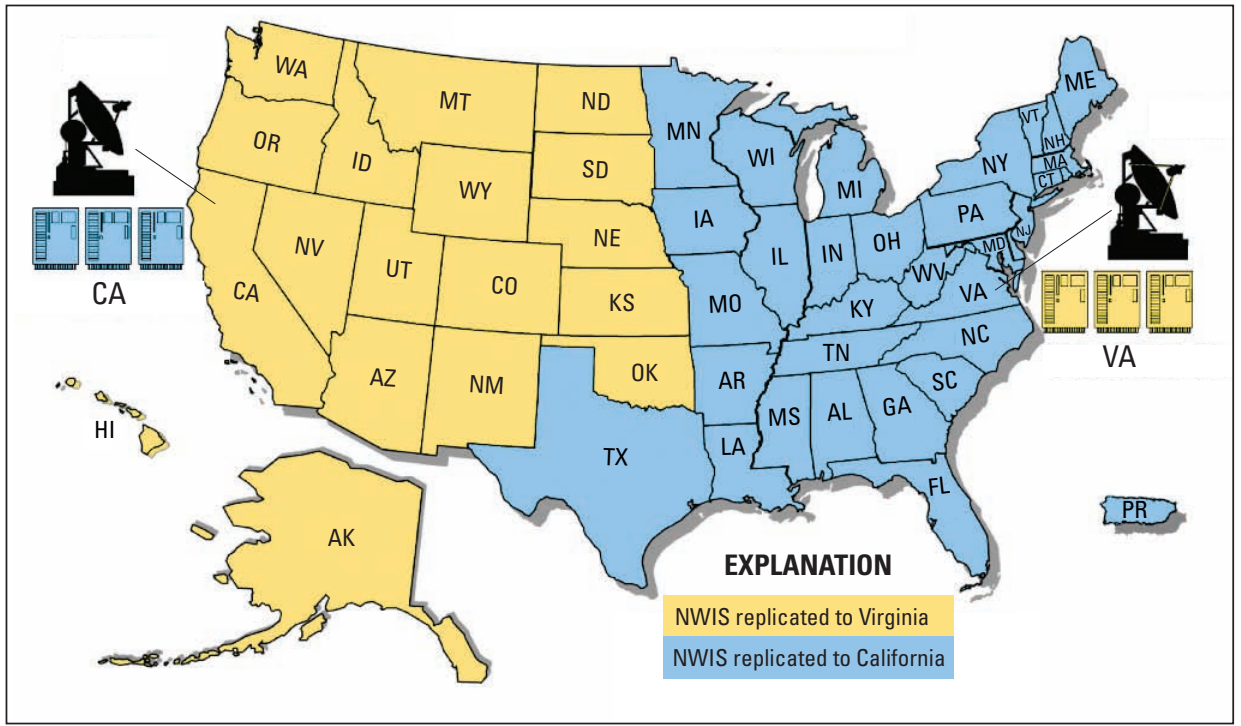

Figure 16. Backup system for receiving and processing real-time streamflow data. to meet long-term national needs for streamflow information while ensuring that local needs continue to be met. More information about NSIP is available at http://water.usgs.gov/nsip/.

The USGS continues to evaluate the activities carried out under NSIP to ensure that the program design remains valid and that activities are conducted in an efficient and cost-effective manner. Several evaluations of NSIP have been conducted, including by the (1) Advisory Committee on Water Information Streamgaging Task Force (http://water. usgs.gov/nsip/taskforce/task_force.html), (2) National Research Council (NRC) (http://water.usgs.gov/nsip/nasreport/ es/NRC_Report.html), (3) U.S. Government Accounting Office (http://www. gao.gov/new.items/d05376.pdf), and (4) National Hydrologic Warning Council (http://water.usgs.gov/nsip/pubs/ nhwc_report.pdf). The NRC concluded "...that the National Streamflow Information Program is a sound, well-conceived program that meets the nation's needs for streamflow measurement, interpretation, and information delivery."

The USGS strives to operate a national streamgaging program that is efficient, relevant, cost effective, and robust, and is dedicated to its continuous improvement. flow Information Program (NSIP). The plan for NSIP was developed to provide a national perspective, guidance, planning, and leadership for streamgaging activities of the USGS. The NSIP plan provides for a unified, stable network of streamgages

\section{References Cited}

Nielsen, J.P., and Norris, J.M., 2007, From the river to you-USGS real-time streamflow information ... from the National Streamflow Information Program: U.S. Geological Survey Fact Sheet 2007-3043, 4 p.

Olson, S.A., and Norris, J.M., 2007, U.S. Geological Survey streamgaging . . . from the National Streamflow Information Program: U.S. Geological Survey Fact Sheet 2005-3131, 4 p.

Ruhl, C.A., and Simpson, M.R., 2005, Computation of discharge using the indexvelocity method in tidally affected areas: U.S. Geological Survey Scientific Investigations Report 2005-5004, 31 p.

\section{By Stephen F. Blanchard}

For additional information visit

http://water.usgs.gov/nsip/

or contact:

J. Michael Norris

U.S. Geological Survey

603-226-7847; mnorris@usgs.gov 